\title{
Konversi Agama \\ pada Masyarakat Suku Minangkabau
}

\author{
Kurnial Ilahi \\ UIN Sultan Syarif Kasim - Riau \\ kurnial.ilahi@uin-suska.ac.id \\ Jamaluddin Rabain \\ UIN Sultan Syarif Kasim - Riau \\ Jamaluddin1@uin-suska.ac.id \\ Suja'i Sarifandi \\ UIN Sultan Syarif Kasim - Riau \\ asyuja@gmail.com
}

\begin{abstract}
Abstrak
Indonesia is one of the countries with a background of people who have different religious beliefs. So in social life, it is very necessary. Community life with different beliefs, it is able to influence self-confidence to change beliefs. This also happened to the people of West Sumatra who had a religious philosophy of life. This research is a descriptive study, using interview analysis techniques and direct observation of the sample of research, namely scholars and religious figures in West Sumatra. Based on the results of the study, it was found that religious conversion occurred in West Sumatra that causes the decreasing of Islamic religions number and the increasing growth of Christianity. The religious conversion occurs because of several influential factors. Factors that cause religious conversion to Minangkabau people from Islam to Christianity include (1) West Sumatra and the Minangkabau tribe are the main targets of International Christianization (2) Development of educational facilities and infrastructure. Social and health service units (3) Educational background, experience, social and social environment (4) Marital status and family relationships.
\end{abstract}


[Indonesia merupakan salah satu Negara dengan latar belakang masyarakat yang memiliki keyakinan beragama berbeda-beda, sehingga dalam kehidupan sosial bermasyarakat sangat diperlukan. Kehidupan bermasyarakat dengan keyakinan yang berbeda, maka mampu mempengaruhi keyakinan diri untuk berpindah keyakinan. Hal ini juga terjadi pada masyarakat Sumatra Barat yang memiliki falsafah kehidupan yang agamis. Penelitian ini merupakan penelitian deskriptif, menggunakan teknik analisis wawancara dan observasi langsung terhadap sampel penelitian yaitu ulama dan tokoh-tokoh agama di Sumatera Barat. Berdasarkan hasil penelitian diperoleh bahwa konversi agama banyak terjadi d Sumatera Barat, hal ini ditandai dengan menurunnya jumlah agama Islam dan meningkatnya pertumbuhan agama Kristen. Terjadinya konversi agama banyak dipengaruhi oleh beberapa faktor, Faktor-faktor penyebab konversi agama pada masyarakat suku Minangkabau dari pemeluk Islam menjadi pemeluk Kristen diantaranya (1) Sumatra Barat dan masyarakat suku Minangkabau menjadi target utama Kristenisasi Internasional, (2) Pembangunan sarana dan prasarana pendidikan, unit pelayanan sosial dan kesehatan, (3) Latar belakang pendidikan, pengalaman, lingkungan sosial dan pergaulan, (4) Status perkawinan dan hubungan keluarga.]

Keywords: conversion, religion, minangkabau

\section{Pendahuluan}

Manusia sebagai makhluk sosial yang sekaligus juga makhluk individual, memiliki perbedaan antara yang satu dengan yang lainnya. Adanya perbedaan inilah yang menyebabkan mengapa seseorang baik individu ataupun komunitas sosial senang terhadap suatu obyek, atau sebaliknya yaitu membenci obyek tersebut. Hal ini sangat tergantung bagaimana individu menanggapi obyek tersebut dengan persepsinya, dan pada kenyataannya sebagian besar sikap, tingkah laku dan penyesuaian manusia ditentukan oleh persepsinya. ${ }^{1}$ Dengan adanya persepsi tersebut akan terbentuk sikap, yaitu suatu kecenderungan

\footnotetext{
${ }^{1}$ Bimo Walgito, Pengantar Psikologi Umum (Yogyakarta: Andi Offset, 2007), 25.
} 
yang stabil untuk berlaku atau bertindak secara tertentu di dalam situasi yang tertentu pula. ${ }^{2}$

Islam sebagai agama perdamaian, diwahyukan oleh Tuhan kepada Nabi Muhammad melalui perantara malaikat Jibril, yang ajaranajarannya tentang ke-Esaan Tuhan, persaudaraan umat manusia, dan berbagai aspek kehidupan. ${ }^{3}$ Namun dalam pandangan umat Islam, masyarakat Eropa atau Barat Kristen pada umumnya dipersepsikan negatif. ${ }^{4}$ Ketika di Barat, fenomena konversi agama telah terjadi di kalangan Elit, Pastur, Pendeta, dan Dosen dari agama Kristen berpindah agama dan memilih Islam sebagai agama baru mereka, fenomena ini juga terjadi di Indonesia bahkan pada masyarakat dan suku yang fanatik sebagai penganut Islam seperti yang terjadi masyarakat suku Melayu dan masyarakat suku Minangkabau.

Seorang Pendeta bernama Yanwardi Koto, asal Lubuk Basung, Agam - Sumatera Barat adalah asli orang Minang yang banyak memurtadkan warga Minangkabau, baik di pelosok maupun di kota, yang mengakibatkan terjadinya penurunan jumlah umat Islam. Data BPS 2010 menjelaskan adanya penurunan yang sangat signifikan jumlah umat Islam di Kecamatan Koto Tangah - Padang - Sumatera Barat, jumlah umat Islam dari 164.675 orang tahun 2009 menjadi 158.469 orang umat Islam pada tahun 2010, berkurang sebanyak 6206 orang dalam jangka waktu 1 tahun, sementara Agama lain mengalami peningkatan yang sangat signifikan, Agama Katolik dari 310 orang tahun 2009 menjadi 1.065 tahun 2010, naik 755 orang dalam 1 tahun. Agama Protestan dari 975 tahun 2009 menjadi 2.376 tahun 2010, naik 1401 orang dalam jangka 1 tahun. ${ }^{5}$

Selain itu interaksi antara aspek-aspek keagamaan dengan aktivitas-aktivitas sosial yang lain sulit dipisahkan, sehingga aspekaspek keagamaan tersebut dapat melahirkan makna sosial tertentu dalam manivestasinya, dimana salah satu wujud dari perkembangan

2 W.A. Gerungan, Psikologi Sosial (Bandung: Eresco, 1980), 137. Mar'at, Sikap Manusia, Perubahan serta Pengukurannya (Jakarta: Ghalia Indonesia, 1981), 11.

3 Harun Nasution, Islam Ditinjau Dari Berbagai Aspeknya, Vol. I (Jakarta: Bulan Bintang, 1991), 9. Maulana Muhammad Ali, Islamologi (Din al-Islam), Terjemahan PT (Jakarta: Ikhtiar Baru Van Hoeve, 2000), 2.

${ }^{4}$ Maxime Rodinson, Europe and the Mystique of Islam (London: LB. Tauris \& Co, 1988), dalam google_book, 2014, 3.

5 "Geliyat Kristenisasi di Ranah Minang", dalam https:/ / cabya iman cahaya kebenaran islam word press.com/2013/11/16/geliyat-kristenisasi-di-ranah-minang/, diakses Tanggal 25 Maret 2016. 
agama pada seseorang diantaranya adalah terjadinya tindakan konversi agama.

\section{Landasan Konseptual Konversi Agama}

Konversi dalam Kamus Umum Bahasa Indonesia diartikan sebagai perubahan dari satu sistem pengetahuan ke sistem yang lain, perubahan dari satu bentuk, rupa dan sebagainya ke bentuk, rupa yang lain. ${ }^{6}$ Sedangkan agama dapat diartikan sebagai suatu ketaatan atau penyerahan diri kepada kekuatan yang lebih tinggi (gaib) dari manusia, yang dipercaya mengatur dan mengontrol, mengatur jalan alam dan kehidupan manusia. ${ }^{7}$ Kata konversi berasal dari bahasa latin conversion, yang berarti taubat, pindah, berubah. ${ }^{8}$ Dalam bahasa Inggris conversion, yang mengandung pengertian berubah dari suatu keadaan, atau dari suatu agama ke agama lain (change from state of from one religion to another). ${ }^{9}$ Secara umum konversi agama dapat diartikan dengan berubah agama atau masuk agama, bertaubat, berubah agama, berbalik pendirian terhadap ajaran agama atau masuk ke dalam agama, suatu perubahan kepercayaan dan ketaatan terhadap suatu agama yang dianut oleh seseorang, melepaskan kepercayaan terhadap suatu agama dan memeluk atau mempercayai agama lain.

Secara terminologi konversi agama memiliki beberapa pengertian, di antaranya menurut Thouless, konversi agama adalah istilah yang pada umumnya diberikan untuk proses yang menjurus kepada penerimaan suatu sikap keagamaan, proses itu bisa terjadi secara berangsur-angsur atau secara tiba-tiba. Kata "convertion" dalam bahasa Inggris berarti "masuk agama." " Sementara Max Heirich mendeskripsikan konversi agama adalah tindakan seseorang atau kelompok yang masuk atau berpindah ke suatu sistem kepercayaan atau perilaku yang berlawanan dengan kepercayaan yang sebelumnya. ${ }^{11}$

Konversi agama menyangkut masalah kejiwaan dan pengaruh lingkungan, yang memuat beberapa pengertian dengan ciri-ciri sebagai berikut :

\footnotetext{
6 Tim Penyusun Diknas RI, Kamus Umum Bahasa Indonesia (Jakarta: Balai Pustaka, 2001), 592.

${ }^{7}$ Hasan Ali, Ilmu Perbandingan Agama (Yogyakarta: al-Falah, 1995), 6.

8 Jalaluddin, Psikologi Agama (Jakarta: Raja Grafindo, 1996), 245.

${ }^{9}$ D. Hendro Puspito, Sosiologi Agama (Yogyakarta: Kanisius, 1993), 79.

${ }^{10}$ Ibid., 80.

${ }^{11}$ Max Heinrich, Change Of Heart: A Test of Some Widely Theories about Religious Conversion, dalam American Journal Of Sociologi, Volume 83, Nomor 3, 667.
} 
Adanya perubahan arah pandangan dan keyakinan seseorang terhadap agama dan kepercayaan yang dianutnya.

Perubahan yang terjadi dipengaruhi kondisi kejiwaan sehingga perubahan secara berproses atau secara mendadak.

Perubahan tersebut bukan hanya berlaku bagi perpindahan kepercayaan dari suatu agama ke agama lain, tetapi juga termasuk perubahan pendangan terhadap agama yang dianutnya sendiri.

Selain faktor kejiwaan dan kondisi lingkungan maka perubahan itupun disebabkan faktor petunjuk dari yang maha kuasa. ${ }^{12}$

Menurut Zakiyah Daradjat, konversi agama (conversion) berarti berlawanan arah, yang dengan sendirinya konversi agama berarti terjadinya suatu perubahan keyakinan yang berlawanan arah dengan keyakinan semula. ${ }^{13}$ Walter Houston Clork dalam The Psychology of Religion memberikan definisi sebagai berikut: "Konversi agama sebagai pertumbuhan atau perkembangan spiritual yang mengandung perubahan arah yang cukup berarti dalam sikap terhadap ajaran dan tindakan agama." 14

Konversi agama yang dimaksud selain uraian di atas memiliki beberapa pengertian, yaitu:

a. Terjadinya perubahan pandangan dan keyakinan seseorang terhadap agama dan kepercayaan yang dianutnya.

b. Perubahan yang terjadi dipengaruhi oleh kondisi kejiwaan sehingga perubahan dapat terjadi secara berproses atau secara mendadak.

c. Perubahan tersebut bukan hanya berlaku bagi perpindahan kepercayaan dari suatu agama ke agama lain,. tetapi ,juga termasuk perubahan pandangan terhadap agama yang dianutnya sendiri.

d. Faktor kejiwaan dan kondisi lingkungan makna perubahan selain itu juga disebabkan oleh faktor petunjuk dari Tuhan Yang Maha Kuasa. ${ }^{15}$

Adapun faktor-faktor yang mempengaruhi terjadinya konversi agama adalah faktor keluarga, lingkungan tempat tinggal, perubahan status masyarakat, kemiskinan dan pendidikan. ${ }^{16}$

\footnotetext{
12 Ibid., 668.

13 Zakiyah Daradjat, Ilmu Jiwa Agama (Jakarta: PT. Bulan Bintang, 2005), 137.

${ }^{14}$ Ibid., 138.

15 Jalaluddin, Psikologi Agama, 246.

${ }^{16}$ Ibid., 31-32.
} 


\section{Sejarah Masuknya Agama Kristen di Sumatera Barat dan Kristenisasi Pada Masyarakat Suku Minangkabau}

Berdasarkan data yang dihimpun dari hasil wawancara mendalam dengan narasumber yang terdiri dari ulama dan tokoh-tokoh agama Sumatera Barat, ${ }^{17}$ dan didukung dengan data dari studi dokumentasi, diketahui bahwa sejarah dan asal usul masuknya agama Kristen diranah Minang (sebutan populer untuk Sumatera Barat) tidak dapat dipisahkan dari adanya kontak dan relasi perdagangan antara bangsabangsa Barat; Portugis, Belanda, Inggris dan Perancis, dengan masyarakat Minangkabau dari Kerajaan Pagaruyung (1347-1825 M). ${ }^{18}$ Beberapa ahli sejarah menjelaskan bahwa Portugis, pada permulaan abad ke 16 sudah pernah ada utusan Kerajaan Pagaruyung yang datang ke Malaka.

Ketika Belanda merebut Kerajaan Malaka dari tangan Portugis pada tahun 1641, sejak itu Belanda mulai memperbesar pengaruhnya di pesisir barat Sumatera untuk menggantikan pengaruh Aceh. Pada tahun 1664, Belanda mendirikan kantor dagang VOC-nya di Inderapura terus ke Salido, dan ke Pulau Cingkuak. Hal ini dilakukan sebagai strategi untuk menghadapi perlawanan rakyat pesisir yang dikoordinir oleh Kerajaan Pasai - Aceh. Untuk melepaskan pesisir barat pulau Sumatera dari pengaruh Aceh, maka Belanda melakukan perjanjian dengan raja Pagaruyung yang merupakan pemilik sesungguhnya dari daerah tersebut. Oleh raja Pagaruyung Belanda diberikan kebebasan untuk mengatur perdagangannya pada daerah tersebut. Perjanjian itu dilakukan pihak Belanda dengan Sultan Ahmad Syah pada tahun $1668 .^{19}$

Pada Tahun 1684, seorang Portugis Tomas Diaz melakukan kunjungan ke Pagaruyung atas perintah gubernur jenderal Belanda di

\footnotetext{
${ }^{17}$ Tengku Rahman, Ulama Kumpulan - Bonjol - Bukit Tinggi, Wawancara Mendalam, 19 November 2016. Zulfikar, Kepala Seksi Bimbingan Masyarakat Islam Kota Bukit Tinggi, Bukit Tinggi 16 Oktober 2016. Syafrijon, Ketua Majelis Ulama Indonesia (MUI) Kabupaten Lima Puluh Kota, Wawancara Mendalam, Tanjung Sati, 15 Oktober 2016. Ibnu D. Ghani, Ketua Lembaga Pagar Nagari dan Pembina Rumah Muallaf Sumatra Barat, Wawancara Mendalam, Padang 16 Oktober 2016. Syahidul Amin, Kepala Seksi Bimbingan Masyrakat Islam Kota Bukit Tinggi, Wawancara, Padang Panjang, 16 Oktober 2016.

${ }^{18}$ Mardjamni Martamin, et.al, Sejarah Perjuangan Minangkabau, (Padang Sumatra

Barat: MSI Bekerjasama Dengan Dinas Pariwisata Provinsi Sumatra Barat, 2002), 125.

${ }^{19}$ Datoek Toeah, Tambo Alam Minagkabau (Bukit Tinggi, Pusaka Indonesia, 1976), 365.
} 
Malaka. ${ }^{20}$ Sejak saat itu mulailah terbina komunikasi dan perdagangan antara VOC dan Kerajaan Pagaruyung. Sebagai akibat konflik antara Inggris dan Perancis dalam Perang Napoleon, maka Inggris memerangi Belanda dan berhasil menguasai pantai barat Sumatera Barat antara tahun 1795-1819. Thomas Stamford Raffles mengunjungi Pagaruyung di tahun 1818. Raffles menemukan bahwa ibukota kerajaan mengalami pembakaran akibat peperangan yang terjadi. Setelah terjadi perdamaian antara Inggris dan Belanda di tahun 1814, maka Belanda kembali memasuki Padang pada bulan Mei tahun 1819.

Pada abad ke 17 terjadi persaingan dagang yang sangat memuncak antara bangsa Belanda dengan bangsa Inggris di Indonesia. Pada tahun 1684 Belanda dapat mengusir Inggris dari perdagangan di Banten. Sebaliknya Inggris masih dapat bertahan di daerah Maluku dan menguasai perdagangan di daerah pesisir Sumatera Bagian Barat. Pada tahun 1786 inggris berhasil menguasai pulau Penang di Selat Malaka sehingga mereka dapat mengontrol jalan dagang diseluruh pulau Sumatera.

Tahun 1780-1784 terjadi perang antara Inggris dan Belanda di Eropa dan menjalar sampai ke daerah-daerah koloni yang mereka kuasai di seberang lautan. Pada tahun 1781 Inggris menyerang kedudukan Belanda di Padang dari pusat kedudukannya di Bengkulu, dan benteng Belanda di Pulau Cingkuak dihancurkan. ${ }^{21}$ Pada tahun 1793 bangsa Perancis yang pernah datang ke Sumatera Barat, yaitu ketika bajak laut yang dipimpin oleh Kapten Le Me dengan anak buahnya mendarat di Pantai Air Manis Padang, mereka dapat merebut Kota Padang dan mendudukinya selama lima hari. Setelah mereka merampok kota, mereka pergi dan tidak kembali. Pada tahun 1795 Inggris merebut Padang kembali, karena terlibat perang dengan Belanda. ${ }^{22}$

Sejak Pemerintahan Kolonial Belanda mendirikan kantor dagang "VOC (Vereenigde Oostindische Compagnie) nya di Pantai Barat Padang pada tahun 1678 dan menempatkan para pegawainya yang beragama Kristen Protestan, maka sejak saat itu pemeluk Kristen sudah ada

\footnotetext{
${ }^{20}$ F. De Haan, Naar Midden Sumatra in 1684, (Batavia's Hage: Albrecht \&Co. -M, Nijhoff. 40p. 8vo wrs. Tijdschrift voor Indische Taal-, Land- en Volkenkunde,1896), 39.

21 "Kedatangan Bangsa Barat ke Minangkabau," dalam bttp:/ /klik minang. blogspot.co.id/2011/08/ kedatangan - bangsa - barat-ke-minangkabau_19.html, Diakses Tanggal 15 November 2016.

22 Ibid.
} 
dalam kehidupan masyarakat suku Minangkabau. Proyek kristenisasi ketika itu belum menunjukkan aktivitasnya, dan baru dimulai sejak Inggris yang dipimpin oleh Rafles pernah menggantikan posisi Belanda menguasai Pesisir Barat Padang pada tahun 1811-1825, terbukti dengan adanya beberapa orang Missionaris yang ditugaskan oleh Kerajaan Inggris untuk melaksanakan misi kristensisasi di pulau Sumatra. ${ }^{23}$ Sedangkan pemerintah Kolonial Belanda menugaskan Gutzlaff dari Netherland Zending Gospel (NZG) untuk melakukan Kristenisasi di ranah Minang. Namun misinya ini belum berhasil dan ia kembali ke Batavia (Jakarta).

\section{Kristenisasi Pada Masyarakat Suku Minangkabau}

Tahapan gerakan kristenisasi ini dimulai dari kedatangan orangorang Barat sebagai misionaris, zending, pendeta dan pastur, serta pegawai-pegawai, serdadu dan polisi Belanda yang beragama Kristen. Pembangunan geraja pertama kali di Ranah Minang adalah di pantai barat Padang dengan dibangunnya gereja Kristen Protestan Koepelkerk. ${ }^{24}$ Gerakan kristenisasi terlihat semakin meningkat ketika memasuki paruh kedua abad ke 19 dan abad ke 20. Memasuki abad 20, misionaris semakin gencar membangun gereja sekaligus merehabilitasi bangunan gereja yang sudah tua dan rusak. Secara berturut-turut dan terencana, rehabilitasi pembangunan gereja dimulai dari Bukittinggi tahun 1916-1917, Sawah Lunto tahun 1920, Padang tahun 1925 dan Payakumbuh tahun 1933.

Ketika Belanda membangun sarana pendidikan seperti sekolahsekolah dan rumah sakit, fasilitas ini oleh para misionaris, zending, pendeta dan pastur dimanfaatkan untuk mengajak penduduk pribumi atau masyarakat suku Minangkabau berpindah agama menjadi pemeluk Kristen. Namun ternyata masyarakat Minangkabau tidak gampang dimasuki, karena telah terjalin sebuah sistem budaya ikatan simbiotik yang erat antara adat dan Islam dengan falsafah adatnya "Adaik Basandi Syarak, Syarak Basandi Kitabullab" (ABSSBK), ${ }^{26}$ sehingga belum ada masyarakat dari suku Minangkabau yang menjadi pemeluk Kristen ketika itu. Dalam konteks ini Sarah Mantovani mengatakan bahwa suku minangkabau yang ada di

\footnotetext{
23 "Sejarah Gereja di Indonesia" dalam http:// sejarah.co/artikel/geredja_di_ sumatra. htm, Diakses Tanggal 17 November 2016.

24 "Buletin Jum'at Barito Minang", (Edisi: 08 Tahun II / 1 Jumadil Ula 1436 H/20 Februari 2015 M).

${ }^{25}$ Ibid.

${ }^{26}$ Mardjamni, Sejarah Perjuangan, 125.
} 
Sumatera Barat yang memiliki falsafah adat yaitu "Adaik Basandi Syarak, Syarak Basandi Kitabullab" memiliki pengaruh yang kuat bagi keIslaman masyarakat minangkabau. ${ }^{27}$

Gerakan kristenisasi di Ranah Minang semakin menampakkan hasil sejak tahun 1950-an, yaitu melalui beberapa orang Pemuda Minangkabau yang berada di Singapura. Mereka telah lebih dulu masuk Kristen. Ketika pulang ke kampung, mereka melakukan pengabaran injil dan membujuk anak-anak muda Minang untuk berpindah agama menjadi pemeluk Kristen. Cara-cara yang dilakukan ternyata berhasil membawa beberapa orang pemuda Minang masuk Kristen. Kelompok inilah yang pertama masuk Kristen. Tetapi dengan kondisi ekonomi yang serba sulit, serta didukung oleh janji tentang hal-hal yang sangat kontra-produktif dengan sikap dasar orang Minang, lama kelamaan tujuan misi terungkap sehingga banyak diantara mereka yang menyatakan keluar dan kembali lagi kepada Islam. ${ }^{28}$

Gerakan kristenisasi semakin jelas dan meningkat sejak tahun 1950-an, seiring dengan adanya program transmigrasi di Obilin dan Sawahlunto. Bersamaan dengan itu, misi kristenisasi juga dilakukan melalui asimilasi masyarakat Minang melalui perkawinan. Namun, pendekatan ini ditolak secara mentah-mentah oleh masyarakat Minang, bahkan menimbulkan reaksi keras dari berbagai kalangan. Meskipun demikian masih ada yang berhasil. Seiring dengan itu, pendirian gereja pun semakin gencar dilakukan ditengah-tengah komunitas umat Islam, ditambah dengan menjamurnya unit-unit pelayanan sosial, kemanusiaan dan kesehatan.

Pada tahun 1970-an proyek kristensisasi dilakukan dengan cara mendirikan Rumah Sakit Baptis Immanuel di Bukittinggi, akan tetapi misi mereka cepat tercium dan akhirnya ditolak. ${ }^{29}$ Keberhasilan menggagalkan proyek kristensisasi di ranah Minang tidak terlepas dari peran semua komponen masyarakat Minang, terutama Buya H. M. D. Dt. Palimo Kayo, mantan Ketua MUI Sumbar, Buya Mohd. Natsir, Buya Hamka, mantan Ketua MUI Pusat. Untuk menghambat gerakan kristenisasi di ranah Minang, di Bukit Tinggi telah dibangun Rumah Sakit Islam Ibnu Sina dan Rumah Sakit Immanuel diambil alih oleh

\footnotetext{
${ }^{27}$ Sarah Mantovani, Kristenisasi Cengkeram Ranah Minang, dalam http:// www. academia.edu/ 4382836 /Hidayatullab_Kristenisasi_Cengkeram_Ranah_Minang, Dikases Tanggal 25 Maret 2016.

28 Buletin Jum'at Barito Minang, (Edisi: 08 Tahun II / 1 Jumadil Ula 1436 H / 20 Februari 2015 M).

${ }^{29}$ Ibid.
} 
pemerintah dengan mengubah nama dan statusnya menjadi Rumah Sakit Ahmad Mukhtar.

\section{Pendeta dan Pemeluk Agama Kristen Dari Suku Minangkabau}

Tercatat sudah 623 orang dari suku Minangkabau yang sudah dikristenkan sejak tahun 2000-2005, dan sampai dengan tahun 2012 sebagaimana dilaporkan oleh Persekutuan Gereja Indonesia (PGI), bahwa orang Minangkabau yang sudah berpindah agama dari Islam menjadi pemeluk Kristen yang telah mencapai 30.000 jiwa yang tersebar di seluruh penjuru dunia. ${ }^{30}$ Berdasarkan jumlah tersebut, tercatat sudah ada 30 orang dari suku Minangkabau yang telah menjadi pendeta, dan aktif dalam proyek kristensisasi di ranah Minang dan pada masyarakat suku Minangkabau di seluruh dunia. Berikut ini dapat dikemukakan beberapa nama orang Minangkabau yang sudah menjadi pendeta adalah:

\section{(1) Pendeta I.F.M. Salim Alias Abdoel Chalid Salim (Adik Haji Agus Salim, Pahlawan Nasional) ${ }^{31}$}

Abdoel Chalid Salim dilahirkan di Tanjung Pinang (Kepulauan Riau), pada 24 November 1902. Awalnya ia seorang muslim, kemudian menjadi komunis (masuk PKI) dan akhirnya pindah ke agama Kristen Katolik dan menjadi Penginjil, berganti nama menjadi Ignatius Franciscus Michael Salim (disingkat: I.F.M. Salim). ${ }^{32}$ Ayahnya berasal dari Koto Gadang, Sutan Muhammad Salim, pernah bertugas di kota 'dollar' Kepulauan Riau sebagai seorang Hoofdd Jaksa dalam jajaran Departemen BB Belanda yang sudah ditugaskan di banyak tempat, termasuk di Padang dan Medan.

Abdoel Chalid Salim memiliki 13 orang bersaudara, tapi hanya 7 orang yang berumur panjang, yang tertua adalah Haji Agus Salim yang kemudian menjadi diplomat kawakan Indonesia. Chalid bersekolah di MULO Batavia tahun 1923, mengikuti

30 “Tahun 2012, Orang Minangkabau Sudah Murtad Mencapai 30.000 Jiwa," dalam bttps: / / www.

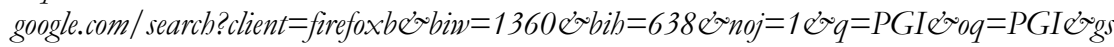
_l=serp.3...518389.519188.0.522201.3.3.0.0.0.0.0.0..0.0....0...1c.1.64.serp..3.0.0.CAE L-R4Nirc, Diakses Tanggal 20 November 2012.

31 Suryadi, "Chalid Salim; Dari Simpatisan PKI ke Kayu Salib," dalam http:/ / niadilova. blogdetik. com/index.php / archives/1051, dan https:/ / mahara djo.wordpress.com/2015/10/21/chalid-salin-dari-simpatisan-pki-ke-kayu-salib/, Diakses Tanggal 15 November 2016.

32 "Pemurtadan di Minangkabau" dalam https:// soeloebmelajoe.wordpress. com/ 2013/ 10/29/ pemurtadan-di-minangkabau/, Diakses Tanggal 15 November 2016. 
ayahnya yang memilih tinggal di ibukota Hindia Belanda itu setelah pensiun. Setelah itu ia berkerja di onderneming Soember Moedjoer di Lumajang. Kemudian ia mengikuti saudaranya, Jacob Salim, di Pontianak, dan menjadi anggota redaksi Halilintar Hindia, sebuah terbitan berkala yang menjadi corong PKI, serta mendirikan Partai Sarekat Rakyat dengan Koesno Goenoko.

Kemudian Abdoel Chalid Salim kembali ke Jawa dan menetap ke Surabaya. Tahun 1925 Pemerintah Kolonial Belanda melakukan politik pembersihan. Abdoel Chalid Salim terpaksa kembali ke kampungnya di Koto Gadang. Agen-agen Politiek Inlichting-dienst Belanda mencokoknya di Medan pada 12 Oktober 1927. Pada tahun itu juga ia dikirim ke Digul. Tahun 1943, menyusul serbuan tentara Jepang ke Indonesia, Chalid Salim dan para digulis lainnya diungsikan Belanda ke Australia. Di Melbourne ia bekerja untuk terbitan mingguan "Penjuluh" yang menjadi media 'Nederlandsch-Indische propaganda' di bawah NIGIS (Netherlands Indies Government Information Services). Inilah yang disebut oleh Harry Poeze sebagai 'the strange alliance of Dutch authorities and Digoel exiles in Australia, 1943-1945. Abdoel Chalid Salim meninggal di Belanda pada 10 Maret 1985 dan dimakamkan di Pemakaman Rijswijk Eikelenburg, Zuid-Holland.

\section{(2) Pendeta Willy Amrul (1927-2012) $)^{33}$}

Willy Amrul memiliki nama asli Abdul Wadud Karim Amrullah (AWKA), adik seayah dari Buya Hamka, lahir pada tanggal 7 Juni 1927 di Agam, Sumatera Barat. Abdul Wadud atau Willy Amrull lahir sebagai anak tunggal dari istri ketiga Abdul Karim Amrullah (Haji Rasul) yaitu Siti Hindun. Ia merupakan adik lain ibu dari Abdul Malik Karim Amrullah (HAMKA). Abdul Wadud meninggalkan Minangkabau pada 8 Agustus 1941 ke Sukabumi.

Abdul Wadud berangkat ke Rotterdam dengan bekerja sebagai tukang binatu di kapal MS Willem Ruys yang berangkat dari Tanjung Priok pada Februari 1949. Selanjutnya ia meneruskan petualangan ke Amerika Serikat dan Amerika Selatan pada 1950 sebelum akhirnya memutuskan untuk menetap di San Francisco, California. Abdul Wadud mendirikan IMI (Ikatan Masyarakat Indonesia) di California pada tahun 1962. Kemudian

${ }^{33}$ Abdul Wadud Karim Amrullah, Dari Subub Hingga Malam (Perjalanan Seorang Putra Minang Mencari Jalan Kebenaran). (Jakarta: PT. BPK Gunung Mulia, 2011), 65. 
ia menikah dengan Vera Ellen George, seorang gadis Indo, pada 6 Juni 1970, dan pada tahun 1983, Abdul Wadud dibaptis oleh Pendeta Gereja Baptis Gerard Pinkston di Kebayoran Baru. Tidak lama kemudian Abdul Wadud ditahbiskan menjadi pendeta di Gereja Pekabaran Injil Indonesia (GPII) (sekarang Gereja Misi Injili Indonesia/GMII) di California dan dikenal dengan nama Pendeta Willy Amrull.

Willy Amrull di Sumatera Barat dikenal sebagai Pendeta Willy. Pada tahun 1999, dirinya jadi perbincangan ramai karena Kasus Wawah yang menghebohkan masyarakat Sumbar. Pada kasus tersebut, Pendeta Willy bersama Yanuardi Koto menjadi "aktor" penting dalam upaya kristenisasi di Sumatera Barat.

\section{(3) Pendeta Akmal Sani ${ }^{34}$}

Minangkabau tidak bisa dipisahkan dari postulat adat "Adiak basandi Syarak, Syarak basandi Kitabullah" (Tradisi bersendikan Syariat, Syariat bersendikan Kitabullah al-Qur'an dan Sunnah Rasul). Tetapi, sekarang ranah Minang dirambah gerakan Kristenisasi. Dengan dipelopori oleh murtadnya Akmal Sani, putera daerah asli asal Pangkalan Koto Baru, Payakumbuh, yang kini menjadi pendeta di Jakarta. Untuk memuluskan program pemurtadan di ranah Minang, dibentuklah Persekutuan Kristen Sumatera Barat (PKSB) yang disuport dengan Kitab Injil Bahaso Minang yang pertama kali diterbitkan tahun 1996. Sebagai pendeta, aktifitas Akmal Sani cukup padat dalam acara kesaksian dan sebagai pengajar (dosen) Islamologi diberbagai gereja dan kampus (School of Ministry di Bethany, dll).

Peranan pendeta Akmal Sani sangat besar dalam merombak ranah Minang "Adiak basandi Syarak, Syarak basandi Kitabullah" menjadi kawasan "Adiak dan Syarak basandi Yesus dan Injil." Dia adalah alat propaganda sekaligus profil teladan di kalangan murtadin urang awak. Terbukti, kaset ceramah kesaksian pendeta Akmal Sani yang menyelewengkan penafsiran ayat-ayat al-Qur'an beredar luas hampir ke seluruh nusantara.

${ }^{34}$ Ibnu Aqil D. Ghani, Pendeta Mantan Minangkabau, (Padang: LAD Rumah Muallaf Indonesia, 2016), 69-72. 


\section{(4) Pendeta Yanwardi Koto ${ }^{35}$}

Yanwardi berasal dari Lubuak Basuang Kabupaten Agam, dahulunya bersukukan Koto. Yanwardi Koto telah menjadi seorang Pendeta dan menjabat sebagai Ketua Yayasan Sumatera Barat yang berkantor di Jakarta, sebagai lembaga pencari dana dari luar negeri dan pengatur misi pemurtadan. Selain memiliki yayasan, dia juga mendirikan Gereja Kristen Nazarene Rantau Jakarta atau biasa disingkat GKN Rantau Jakarta. ${ }^{36}$

Gereja tersebut menggunakan simbol-simbol Minangkabau dalam melaksanakan upacara keagamaan mereka seperti menggunakan beberapa ukiran khas Minangkabau pada ruangan kebaktian mereka. Menggunakan pakaian adat Minangkabau, simbol-simbol rumah gadang, dan lain sebagainya. Gereja inilah yang menjadi tempat Yanwardi "menggembalakan dombadombanya" yang tersesat. Pendeta Yanwardi Koto pernah menyebarkan photo dirinya dengan memakai pakaian kebesaran seorang penghulu dalam melaksanakan ritual agamanya di gereja. $^{37}$

\section{(5) Pendeta Sofyan ${ }^{38}$}

Pendeta Sofyan berasal dari Lintau, Kabupaten Tanah Datar, pimpinan Sekolah Tinggi Teologia (STT) milik Doulos World Mission (DWM) Amerika, berada di desa terpencil di bilangan Majalengka, Jawa Barat. Merupakan pusat pendidkan dan pembinaan Pendeta untuk Minangkabau abad ke 21. Saat ini DWM sedang melaksanakan Proyek Yerikho 2000, yaitu program pengkristenan wilayah Jawa Barat, dengan sentra kegiatan digerakkan di kawasan pinggiran Jakarta. Proyek ini bertujuan "mewujudkan Kerajaan Allah di bumi Parahyangan menyongsong abad XXI." Menurut Hendrik Kraemer, peneliti dan penginjil dari Belanda, Jawa Barat adalah wilayah "paling gelap" di Indonesia dan sangat tertutup bagi Injil. Karena itu aktivis DWM bertekad, "Kita harus merebut tanah Pasundan

\footnotetext{
35 Ibnu Aqil, Pendeta Mantan, 81-83.

${ }^{36}$ Gereja Nazere lahir di Amerika Serikat pada tahun 1908, masuk ke Indonesia pada tahun 1999. Lihat: https:// sites. google.com / site/ jemaatshiloh / what-s- happening dan http:/ / indonazarene.org/about-us/, Diakses Tanggal 20 November 2016.

${ }^{37}$ Gereja ini diperuntukkan untuk orang Kristen yang berasal dari bekas orang Minangakabau. Lihat: http:/ / www.streetdirectory.com/Gereja-Kristen-Nazarene-Rantau/, Diakses Tanggal 20 November 2016.

${ }^{38}$ Ibnu Aqil, Pendeta Mantan, 83.
} 
bagi Kristus." Yerikho 2000 juga digerakkan di Sumatera Barat, Riau, Jambi, Bengkulu, Lampung, Kalimantan Tengah, dan Kalimantan Barat. Pusat kegiatan DWM berada di kawasan Rawamangun (Jakarta Timur) dan Tangerang (Banten). ${ }^{39}$

\section{Faktor-Faktor Penyebab Terjadinya Konversi Agama Pada Masyarakat Suku Minangkabau}

Terjadinya konversi agama dari pemeluk Islam menjadi pemeluk Kristen pada masyarakat suku Minangkabau, disebabkan karena adanya beberapa faktor. Faktor penyebab yang paling utama adalah Missionaris dan Zending, mereka telah menjadikan Sumatra Barat dan masyarakatnya yaitu suku Minangkabau sebagai target utama Kristenisasi sejak zaman penjajahan Inggris dan Belanda hingga sekarang.

Kerajaan Belanda atau Pemerintah Kolonial Belanda yang bekerjasama dengan Netherland Zending Gospel (NZG) pernah menugaskan Gutzlaff untuk melakukan Kristenisasi di Sumatra Tengah (Sebutan untuk Sumatra Barat ketika itu), Walaupun misinya belum berhasil dan ia kembali ke Batavia (Jakarta) karena sedang terjadi Perang Paderi tahun 1825-1830, ${ }^{40}$ tetapi bersamaan dengan masuknya Penjajah Belanda di ranah Minang, ikut di dalamnya para misionaris, zending, pendeta dan pastur dengan dua misi utama, yaitu: (1) memimpin kebaktian atau peribadatan di gereja bagi pemeluk Kristen dan (2) mengajak penduduk pribumi atau masyarakat suku Minangkabau untuk berpindah agama dari Islam menjadi pemeluk Kristen. ${ }^{41}$

Bernard Abdul Jabbar, mantan Missionaris dan Aktivis Kristen, mengatakan bahwa wilayah Jawa Barat dan Sumatra Barat menjadi target kristenisasi internasional. Penaklukan Provinsi Jawa Barat dan Sumatera Barat merupakan indikator keberhasilan proyek kristenisasi internasional. Penyumbang terbesar kristenisasi di Indonesia adalah

\footnotetext{
${ }^{39} \mathrm{http}: / /$ id.answers.yahoo.com/question/ index?qid=20110717075217AAMEY02, dan bttp://blogminangkabau.wordpress.com/2012/04/19/minang kabau- sumatera-baratdalam-incaran-salibiyah-pemurtadan/.

${ }^{40}$ Sjafnir Aboe Nain, Tuanku Imam Bonjol Sejarab Intelektual Islam di Minangkabau, (Padang, Penerbit ESA, 2008), 22. Karel A. Steenbrink, Catholics in Indonesia 18081942 (Leiden: KITLV Press, 2003), 36.

${ }^{41}$ Buletin Jum'at Barito Minang, (Edisi: 08 Tahun II / 1 Jumadil Ula 1436 H / 20 Februari 2015 M). Ibnu D. Ghani, Ketua Lembaga Pagar Nagari dan Pembina Rumah Muallaf Sumatra Barat, Wawancara Mendalam, Padang 16 Oktober 2016. Syahidul Amin, Kepala Seksi Bimbingan Masyrakat Islam Kota Bukit Tinggi, Wawancara, Padang Panjang, 16 Oktober 2016.
} 
Sumatera Barat, dan masyarakat yang paling mudah menerima kehadiran misionaris adalah masyarakat Mentawai, karena di sana ada Rumah Kasih Nazaret Minangkabau. ${ }^{42}$ Benhard Abdul Jabbar juga mengingatkan masyarakat Minangkabau bahwa kristenisasi menjadikan Sumatera Barat sebagai target misi di Indonesia seperti halnya Jawa Barat. Jika Manado disebut sebagai negeri Yesus, Manokwari sebagai kota Injil, Sumatera Barat disebut sebagai negeri 'tuaian' (panen raya). ${ }^{43}$

Pendeta Sofyan yang berasal dari Lintau, Kabupaten Tanah Datar, memimpin Sekolah Tinggi Teologia (STT) milik Doulos World Mission (DWM) Amerika, di desa terpencil di Majalengka, Jawa Barat. Lembaga yang dipimpinnya ini merupakan pusat pendidikan dan pembinaan Pendeta untuk Minangkabau abad ke 21 sebagai bagian dari pelaksanaan Proyek Yerikho 2000, yaitu program pengkristenan wilayah Jawa Barat, dengan sentra gerakan kegiatan di kawasan pinggiran Jakarta. Proyek ini bertujuan "mewujudkan Kerajaan Allah di bumi Parahyangan menyongsong abad XXI." Yerikho 2000 juga digerakkan di Sumatera Barat, Riau, Jambi, Bengkulu, Lampung, Kalimantan Tengah, dan Kalimantan Barat. Pusat kegiatan DWM berada di kawasan Rawamangun (Jakarta Timur) dan Tangerang (Banten). ${ }^{44}$

Yanwardi Koto telah menjadi seorang Pendeta dan menjabat sebagai Ketua Yayasan Sumatera Barat yang berkantor di Jakarta, sebagai lembaga pencari dana dari Luar Negeri dan pengatur misi pemurtadan. Selain memiliki yayasan, dia juga mendirikan Gereja Kristen Nazarene Rantau Jakarta atau biasa disingkat GKN Rantau Jakarta.Ia akatif dalam melakukan misinya terutama sekali kepada perantau orang-orang Minangkabau di Sumatra Barat. Gereja tersebut menggunakan simbol-simbol Minangkabau dalam melaksanakan upacara keagamaan mereka seperti menggunakan beberapa ukiran khas Minangkabau pada ruangan kebaktian mereka. Menggunakan pakaian adat Minangkabau, simbol-simbol rumah gadang, dan lain sebagainya.

\footnotetext{
42"Jabar dan Sumbar Jadi Target Kristenisasi Internasional," dalam bttp:// www. bidayatullah.com, Diakses Tanggal 17 November 2016.

43"Mantan Pendeta: Hati-hati Kristenisasi Minangkabau Negeri Tuaian," dalam bttp:// wnw.beritamuallaf.com, Diakses Tanggal 17 November 2016.

${ }^{44}$ bttp:// id.answers.yahoo.com/question/ index?qid=20110717075217 AAMEY02, dan bttp://blogminangkabau.wordpress.com/2012/04/19/minang kabau -sumatera-baratdalam-incaran-salibiyah-pemurtadan/.
} 
Berdasarkan uraian di atas dapat diketahui bahwa maraknya proyek Krsitenisasi di Sumatra Barat dan Masyarakat suku Minangkabau, dipengaruhi oleh faktor yang secara eksternal Missionaris dan Zending yang telah menjadikan Sumatra Barat dan masyarakatnya sebagai target utama Kristenisasi sejak zaman penjajahan Inggris dan Belanda hingga sekarang. Sumatera Barat dan masyarakat suku Minangkabau menjadi daerah target utama Kristenisasi di Indonesia, karena daerah ini adalah penghasil intelektual dan pengusaha Muslim.

\section{Menurunnya Populasi Penduduk Muslim Suku Minangkabau}

Pertumbuhan dan perkembangan penganut agama Kristen di Provinsi Sumatra Barat setiap tahunnya mengalami peningkatan yang signifikan, yang berarti bahwa dengan adanya proyek Kristenisasi ini jumlah populasi penduduk Muslim di Sumatra Barat akan terus mengalami penurunan, dan sampai hari ini sudah tercatat sudah 623 orang Minangkabau yang sudah dikristenkan sejak tahun 2000-2005, dan sampai dengan tahun 2012 sebagaimana dilaporkan oleh Persekutuan Gereja Indonesia (PGI) bahwa orang Minangkabau yang sudah berpindah agama dari Islam menjadi pemeluk Kristen telah mencapai 30.000 jiwa. $^{46}$ Dari jumlah tersebut, ada 30 orang Minangkabau yang telah menjadi Pendeta dan aktif dalam proyek kristensisasi di ranah Minang dan masyarakat suku Minangkabau, sehingga dengan menurunnya jumlah populasi penduduk Muslim Sumatra Barat, tentu berpengaruh terhadap penurunan jumlah populasi penduduk Muslim Indonesia.

Data BPS 2010 menjelaskan adanya penurunan yang sangat signifikan jumlah umat Islam di Kecamatan Koto Tangah Padang Sumatera Barat, Jumlah Umat Islam dari 164.675 orang tahun 2009 menjadi 158.469 orang umat Islam tahun 2010 berkurang sebanyak 6206 orang dalam jangka waktu 1 tahun, sementara Agama lain mengalami peningkatan yang sangat signifikan, Agama Katolik dari 310 orang tahun 2009 menjadi 1.065 tahun 2010 naik 755 orang dalam 1 tahun, Agama Protestan dari 975 tahun 2009 menjadi 2.376 tahun 2010, naik 1401 orang dalam jangka 1 tahun. ${ }^{47}$

\footnotetext{
46"Tahun 2012, Orang Minangkabau Sudah Murtad Mencapai 30.000 Jiwa," dalam https: / $/$ www.google. com/ search?client=firefox\&biw $=1360 \& b i b=638 \&$ noj $=1 \& q=P G$ I\&oq=PGI \&ogs, Tanggal 20 November 2012.

47" Geliyat Kristenisasi di Ranah Minang", dalam https:/ / cabya iman cahaya kebenaran islam word press.com /2013/11/16/geliyat-kristenisasi-di-ranab-minang/, Dikases Tanggal 25 Maret 2016.
} 
Penurunan jumlah populasi penduduk Muslim sebagai dampak sosial dari proyek Kristenisasi ini disebabkan karena para pelayan gereja-gereja di Indonesia telah memberikan beberapa instruksi kepada seluruh jemaat Kristen, di antaranya:

(1) Gereja melarang umat Kristen untuk menggunakan KB.

(2) Propaganda pembatasan kelahiran dan keluarga berencana bagi orang Islam dilakukan dengan sangat intensif dan ditunjang dengan berbagai macam cara.

(3) Gereja secara ketat melarang penguasa tanah Kristen untuk menyewakan atau menjual bangunan-bangunan, rumahrumah, toko-toko bagi orang Islam.

(4) Orang-orang Kristen berusaha untuk mengarahkan kebijaksanaan pemerintah agar selalu berorientasi ke Barat terutama ke Amerika.

(5) Orang-orang Kristen berusaha mengusai dan mengontrol informasi, baik melalui media televisi, radio, koran, majalah, buku-buku maupun media yang lainnya.

(6) Orang-orang Kristen berusaha untuk merebut kursi kekuasaan. $^{48}$

\section{Sanksi Adat Bagi Orang Minangkabau Yang Berpindah Agama}

Masyarakat suku Minangkabau tidak dapat dipisahkan dari sistem budaya ikatan simbiotik yang erat antara adat dan Islamdengan falsafah adatnya "Adaik Basandi Syarak - Syarak Basandi Kitabullab" (ABS-SBK), ${ }^{49}$ yang berarti bahwa masyarakat suku Minangkabau identik dengan Islam. Oleh karena itu ketika ada anggota masyarakat suku Minangkabau yang berpindah agama menjadi pemeluk Kristen, maka secara otomatis ia disebut sebagai orang yang murtad, telah menyalahi adat dan dianggap bukan sebagai bahagian dari orang Minangkabau.

Dalam kasus Yanwardi Koto, pendeta Kristen asli Minang berasal yang banyak terlibat dalam berbagai pemurtadan atau Kristenisasi dengan cara menculik, merusak kehormatan, dan memaksa pindah agama pada masyarakat suku Minangkabau, menyebabkan para Ninik Mamak Payuang Kaum Koto Datuk Tumangguang Nagari Lubuk Basung membuat pernyataan pada

\footnotetext{
${ }^{48} \mathrm{Abu}$ Fatimah, "Krsitenisasi di Indonesia," dalam bttp://ke-blog-0.blogspot.co.id/ 2011/11/ kristenisasi-di-indonesia.btml, Diakses Tanggal 18 November 2016.

${ }^{49}$ Mardjamni, Sejarah Perjuangan, 125.
} 
tanggal 18 Juli 1999. Pernyataan tersebut adalah mengenai Yanwardi Koto yang tidak diterima lagi dari keluarga serta dunsanak kaum Koto Datuk Tumangguang Nagari Lubuk Basung dan dibuang sepanjang adat. Mashadi menilai, Yanwardi telah murtad dan bisa dijatuhi hukuman seperti dibunuh, disalib, dipotong kaki dan tangannya secara bersilang, atau diusir dari daerahnya. Memang telah ada kesepakatan adat bahwa ia akhirnya diusir dari kekerabatan secara adat. Namun, ia tetap harus dipantau agar tidak mengajak yang lainnya. Apalagi dengan cara pemaksaan. ${ }^{50}$

\section{Penguatan Peran dan Konstribusi Lembaga Sosial Masyarakat dan Keagamaan (Rumah Muallaf Center, Pagar Nagari, dan MUI)}

Semakin gencarnya proyek krsitenisasi pada masyarakat suku Minangkabau, baik yang berlangsung di ranah Minang maupun di rantau, maka memantik peran dan konstribusi lembaga sosial kemasyarakat dan keagamaan yang ada di lingkungan masyarakat suku Minangkabau. Lembaga sosial kemasyarakatan dan keagamaan yang telah banyak memberikan peranan dan konstribusinya dalam menangani berbagai kasus pemurtadan atau kristenisasi pada masyarakat suku Minangkabau, adalah Rumah Muallaf Center Padang dan Pagar Nagari Sumatra Barat yang dipimpin oleh Ustadz Ibnu Aqil D. Ghani bersama Majelis Ulama Indonesia (MUI) Sumatra Barat mulai dari tingkat provinsi sampai dengan tingkat kabupaten dan kota, Lembaga Kerapatan Adat Minangkabau (LKM). ${ }^{51}$

Dalam upaya membongkar praktik misionaris asing, peran dan konstribusi Rumah Muallaf Center Padang dan Pagar Nagari Sumatra Barat, dalam sebuah wawancara, Ustadz Ibnu Aqil menjelaskan sebagai berikut:

"Setelah menghimpun informasi awal, Paga Nagari menurunkan tim pencari fakta. Saat itu, saya menyamar sebagai petani. Sementara, anggota tim ada yang menyamar sebagai tukang kredit keliling. Setelah hampir sepekan di lapangan, tim akhirnya menemukan fakta bahwa Ralp Charles Lewis Jr adalah penginjil

\footnotetext{
${ }^{50}$ Mardiana Dewi, “Adat Minang Tercoreng Kasus Pemurtadan,” dalam http:/ / wmw. republike.co.id, Diakses Tanggal 18 November 2016.

${ }^{51}$ Tengku Rahman, Ulama Kumpulan- Bonjol - Bukit Tinggi, Wawancara Mendalam, di Kumpulan- Bonjol - Bukit Tinggi, 19 November 2016. Zulfikar, Kepala Seksi Bimbingan Masyrakat Islam Kota Bukit Tinggi, Bukit Tinggi 16 Oktober 2016. Syafrijon, Ketua Majelis Ulama (MUI) Kabupaten Lima Puluh Kota, Wawancara Mendalam, Tanjung Sati, 15 Oktober 2016.
} 
yang berkedok berlibur menghabiskan cuti tahunan di Danau Diateh Alahan Panajang, sang pendeta dari Amerika itu "berdakwah" dari rumah ke rumah penduduk yang terpencil di seberang danau. Ia mendatangi petani di tengah ladang. Tim juga menemukan fakta Lewis Jr menyebarkan kitab injil berbahasa Minang. Robert dan Traccy kepada Tim Paga Nagari malah dengan bangganya mengaku sebagai utusan Yesus ke Ranah Minang, mereka juga membagi-bagikan bibit tanaman transgenik untuk membujuk orang kampung." ${ }^{52}$

Peran dan konstribusi Rumah Muallaf Center Padang dan Pagar Nagari Sumatra Barat ketika ada kasus wanita murtad melalui pernikahan adalah mengidentifikasi persoalan pemurtadan yang kerap terjadi tersebut. Dengan bercermin dari berbagai kasus yang pernah terjadi, ranah Minang menjadi target penghancuran keimanan, moralitas, dan adat istiadat masyarakatnya. Sudah menjadi rahasia umum, jika ingin menguasai Sumatera, kuasai dulu Sumatera Barat. Kenyataan membuktikan bahwa perhatian ormas islam semakin lama semakin besar.

\section{Penutup}

Fenomena konversi agama pada masyarakat suku Minangkabau, dari Penganut Islam menjadi pemeluk Kristen dimulai sejak adanya kontak dan relasi perdagangan antara bangsa-bangsa Barat; Portugis, Belanda, Inggris dan Perancis dengan masyarakat Minangkabau dari Kerajaan Pagaruyung (1347-1825 M). Ketika Pemerintahan Kolonial Belanda mendirikan kantor dagang "VOC (Vereenigde Oostindische Compagnie) nya di Pantai Barat Padang pada tahun 1678 dan menempatkan para pegawainya yang beragama Kristen Protestan, maka sejak saat itu pemeluk Kristen sudah ada dalam kehidupan masyarakat suku Minangkabau.

Faktor-faktor penyebab konversi agama pada masyarakat suku Minangkabau dari pemeluk Islam menjadi pemeluk Kristen adalah (1) Sumatra Barat dan masyarakat suku Minangkabau menjadi target utama Kristenisasi Internasional. (2) Pembangunan sarana dan prasarana pendidikan, unit pelayanan sosial dan kesehatan. (3) Latar belakang pendidikan, pengalaman, lingkungan sosial dan pergaulan. (4) Status perkawinan dan hubungan keluarga.

\footnotetext{
${ }^{52}$ Ibnu Aqil D. Ghani, Ketua Lembaga Muallaf Center Padang dan Ketua Paga Nagari Sumatera Barata, Wawancara, Padang, Sumatra Barat, 15 Oktober 2016.
} 
Sedangkan dampak sosial konversi agama pada masyarakat suku Minangkabau dari pemeluk Islam menjadi pemeluk Kristen adalah (1) Menurunnya jumlah populasi penduduk Muslim Sumatra Barat atau masyarakat suku Minangkabau, Sumatera Barat diklaim sebagai provinsi dengan pertumbuhan dan perkembangan agama Kristen nomor dua di Indonesia yang mencapai angka 7\% setiap tahun. (2) Berlakunya sanksi adat bagi orang-orang Minangkabau yang berpindah agama dari pemeluk Islam menjadi pemeluk Kristen. (3) Menguatnya Peran dan Konstribusi Lembaga Sosial Masyarakat dan Keagamaan (Rumah Muallaf Center, Pagar Nagari, dan MUI).

\section{Daftar Pustaka}

Ali, Hasan. Ilmu Perbandingan Agama. Yogyakarta: al-Falah, 1995.

Amrullah, Abdul Wadud Karim. Dari Subuh Hingga Malam Perjalanan Seorang Putra Minang Mencari Jalan Kebenaran. Jakarta: PT. BPK Gunung Mulia, 2011.

Buletin Jum'at Barito Minang. Edisi: 08 Tahun II/1 Jumadil Ula 1436 H/20 Februari 2015.

Dewi, Mardiana. "Adat Minang Tercoreng Kasus Pemurtadan." Dalam bttp:/ / www.republika.co.id.

Diknas RI, Tim Penyusun. Kamus Umum Bahasa Indonesia. Jakarta: Balai Pustaka, 2001.

Fatimah, Abu. "Krsitenisasi di Indonesia," bttp:/ / kk-blog-0.blogspot.co.id /2011 /11/ kristenisasi-di-indonesia.btml.

Gerungan, W.A. Psikologi Sosial. Bandung: Eresco, 1980.

Ghani, Ibnu Aqil D. Fakta dan Data Pemurtadan; Minangkabau di Bawah Genggaman Pemurtadan Kristenisasi Gaya Dralim, Pola Jin dan Hipnotis. Padang: Penerbit Gerakan Anti Pemurtadan, 2003.

Haan, F. De. Naar midden Sumatra in 1684. Batavia's Hage: Albrecht \&Co. M, Nijhoff. 40p. 8vo wrs. Tijdschrift voor Indische Taal, Land en Volkenkunde, 1896.

Heinrich, Max. Change Of Heart: A Test of Some Widely Theories about Religious Conversion. American Journal Of Sociologi, Volume 83, Nomor 3.

Jaiz, Hartono Ahmad. Fakta dan Data Pemurtadan; Al-Qur'an Dijadikan Sebagai Alat Kristenisasi. Padang: Penerbit Surau, 2003.

Jalaluddin. Psikologi Agama. Jakarta: Raja Grafindo, 1996. Pendeta Mantan Minangkabau. Padang: LAD Rumah Muallaf Indonesia, 2016. 
Mantovani, Sarah. Kristenisasi Cengkeram Ranah Minang. http:/ / wmw. academia.edu/4382836/Hidayatullah_Kristenisasi_Cengkeram_Ranah _Minang.

Martamin, Mardjamni. et.al. Sejarah Perjuangan Minangkabau. Padang Sumatra Barat: MSI dan Dinas Pariwisata Provinsi Sumatra Barat, 2002.

Nain, Sjafnir Aboe. Tuanku Imam Bonjol Sejarah Intelektual Islam di Minangkabau. Padang, Penerbit ESA, 2008.

Nasution, Harun. Islam Ditinjau Dari Berbagai Aspeknya. Jakarta: Bulan Bintang, 1991.

Puspito, D. Hendro. Sosiologi Agama. Yogyakarta: Kanisius, 1993.

Rodinson, Maxime. Europe and the Mystique of Islam. London: LB. Tauris \& Co, 1988.

Steenbrink, Karel A. Catholics in Indonesia 1808-1942. Leiden: KITLV Press, 2003.

Suryadi. "Chalid Salim; Dari Simpatisan PKI ke Kayu Salib.” dalam bttp:/ / niadilova.blogdetik.com/index.php/archives/1051,danhttps:// m abaradjo.wordpress.com/2015/10/21/chalid-salin-dari-simpatisan-pkike-kayu-salib/

Toeah, Datoek. Tambo Alam Minagkabau. Bukit Tinggi: Pusaka Indonesia, 1976.

Walgito, Bimo. Pengantar Psikologi Umum. Yogyakarta: Andi Offset, 2007.

Daradjat, Zakiyah. Ilmu Jiwa Agama. Jakarta: PT. Bulan Bintang, 2005.

\section{Website}

https://cahya iman cahaya kebenaran islam word press.com/2013/11/16/geliyat-kristenisasi-di-ranah-minang http://www.hidayatullah.com http://www.sejarah.co/artikel/geredja_di_sumatra.htm https://www.google.com/search?client=firefox\&biw=1360\&bih=63

$8 \&$ noj=1\&q=PGI\&oq=PGI\&gs

https://soeloehmelajoe.wordpress.com/2013/10/29/pemurtadan-diminangkabau/

http://www.beritamuallaf.com 


\section{Wawancara}

Syahidul Amin. Kepala Seksi Bimbingan Masyrakat Islam Kota Bukit Tinggi.

Tengku Rahman. Ulama Kumpulan- Bonjol - Bukit Tinggi.

Zulfikar. Kepala Seksi Bimbingan Masyrakat Islam Kota Bukit Tinggi. Syafrijon. Ketua Majelis Ulama (MUI) Kabupaten Lima Puluh Kota.

Ibnu Aqil D. Ghani. Ketua Lembaga Pagar Nagari dan Pembina Rumah Muallaf Sumatra Barat. 